\title{
Divine Injunction in John 15: 1-4 and Its Relevance to Sustainable Development in Nigeria
}

\author{
Olusola Igbari ${ }^{1,2}$ \\ ${ }^{1}$ Crowther Graduate Theological Seminary, Abeokuta, Nigeria \\ ${ }^{2}$ Ajayi Crowther University, Oyo, Nigeria \\ Email: igbarisola@gmail.com
}

How to cite this paper: Igbari, O. (2018) Divine Injunction in John 15: 1-4 and Its Relevance to Sustainable Development in Nigeria. Open Access Library Journal, 5: e4963.

https://doi.org/10.4236/oalib.1104963

Received: October 8, 2018

Accepted: November 16, 2018

Published: November 19, 2018

Copyright $\odot 2018$ by author and Open Access Library Inc.

This work is licensed under the Creative Commons Attribution International License (CC BY 4.0).

http://creativecommons.org/licenses/by/4.0/

(c) () Open Access

\begin{abstract}
The New Testament books are full of divine injunctions which were uttered for the purpose of spiritual growth of the readers. They are supernatural commands needed to be obeyed to achieve specific goals. Lawrence Richard like other scholars refers to them as deific, exquisite, hallowed and sacred. The text for consideration in this paper is one of the seven "I am sayings" of Jesus in the Gospel of John. "I am the true vine" (John 15:1). Sustainable spiritual development is key to the survival of life of people as challenges confronting individuals in the contemporary world keep on increasing on daily basis. The symbolism of the "True Vine", used by Jesus Christ to describe the place of his life and mission on earth vis-à-vis the state of humans that necessitated God to incarnate Himself in the person of Christ, is very significant in Johannine Theology. The "Vine" in Israel is a unique plant which everybody appreciates, in the sense that it serves both religious and economic purposes in the land of Israel. It is a "Metaphor" that Jesus Christ chose to describe the importance of his mission on earth. In Johannine Theology, the relationship between the "True Vine," The Vine dresser, and the Branches is pertinent and vital to the understanding of the role of Messiahship in the salvation of human souls. The message in this text on the role of these three important Theological figures is essential to the sustainability of the spiritual development of Jesus' followers and sustainable development in Nigeria especially among the leaders and the led.
\end{abstract}

\section{Subject Areas}

Sociology

\section{Keywords}

Divine Injunction, Sustainability, Sustainable Development and Spiritual Growth 


\section{Introduction}

In recent times, Biblical scholars have engaged themselves in examining some theological statements made by Jesus Christ to his audience and how all these can be applied to the contemporary experience of the Church. This title is one of such areas of concern. For instance, the symbolism of the "True Vine" used by Jesus Christ to describe the significance of his life and ministry on earth vis-a-vis the state of humans that necessitated God to incarnate himself in the person of Jesus Christ is unique in Johannine Theology. Hence, the use of this "Metaphor" further explains to the readers of this gospel, the deeper meaning of the doctrine of incarnation. "God becoming flesh" constitutes a serious problem to an ordinary Jew or Greek in the sense that the person of God who is transcendent by nature can not also be immanent unless He will not be God. But in John's style of writing the use of imagery which the recipients of the gospels of John was used to in practical terms will make them to understand what the writer means by using that language. This paper is an attempt to examine the purpose of the use of the words "The True Vine," the language, and theology and how they apply to the church in the contemporary world.

The method used for this research paper was an exegetical approach to expose the text within the context so as to unravel the hidden nature of Jesus as the messiah who has come to save the living and the dead.

\section{What is Divine Injunction?}

The New Testament is full of divine injunctions which are uttered for specific purposes. They are supernatural commands that need to be obeyed to achieve a specific goal in the lives of humans. They are eternal and holy in nature and also have heavenly goal. Scholars e.g. Lawrence Richard refer to them as Deific, god$1 y$, hallowed and sacred. They are equally supreme ultimate, exquisite, delightful, splendid and also marvelous. They express God's eternal purpose for the lives of His people to ensure and fulfill His divine purpose in His creation.

The text for consideration in this paper is about one of the "I am sayings" in Johannine gospel. The others are found in John 6:35, 51; 8:12; 10:7, 9; 10:11, 14; 11:25 and 14:6. The word "true" in John 15: 1 connotes dependability in the character of the Messiah. It also connotes originality.

The text also confirms the divinity of Jesus which is deific and exquisite. Jesus demonstrated in His earthly ministry his dual nature-humanity and divinity. As the true vine, by implication he is all sufficient for all times at all places and for all humans.

In Theological context, the text as it were, is catalyst to sustainable development. In physical life, health and strength are sustained only through the physical food we eat everyday and obeying health rules. Humans can only be sustained if we draw from the fountain of life-the true vine. The text also confirms that those who do not draw from this wither and go into extinction.

There is a connection between the true vine and the sustainability of those who believe in Him. This is the core of the spiritual implication of the text on the 
lives of true believers. In the interpretation of this text, the grape vine is a prolific plant; a single vine that supports numerous branches and bears many grapes. "In the Old Testament grape symbolized Israel's fulfillment in doing God's work on earth," (Ps 80:8; 15:5; 1-7, Esk. 19:10-14). In the Passover meal, the fruit of the Divine symbolizes God's goodness to his people. Unique aspect of this goodness is exemplified in the sustainability that those who draw from the only true vine enjoy maximally. The summary of John 15:1-4 is found in John 15:4 which says:

Remain in me I will remain in you. No branch can bear fruit by itself unless it remains in the vine; neither can you bear fruit unless you remain in me.

The essence of what Jesus is saying here is the fulfillment of his mission and ministry on earth. It is an evidence of his love and concern for those he has come to save. This verse also proves that each believer has been positioned in the vine, he is charged to remain in union with Christ, not to attain this union but to remain in it.

The Greek word for "abide" is an imperative $\mu \varepsilon เ v a \tau \varepsilon$. Here it is connotative; it encompasses the entire act of abiding and views it as a single event. Organic union with Christ by His followers is mandatory to enjoy the sustainability that this paper is trying to highlight. If the branches can continue to draw from the "True Vine," they will live. Life will be sustained.

\section{What is Sustainable Development?}

The word "Development" is always used when growth is to be measured within a period of time among a given group of people. It relates to "cause to grow greater, fuller or complete." [1]

It is a state in which something is active, visible and measurable within a given period. It can be expressed in various ways of human life-social, political, religious and economic. Hence, sustainable development is a kind of growth that is constant and stable for a period within which that experience is being examined.

According to Stephen Adei, (2009) in his work on "Religion, Culture and Development" says, contemporary students of development have noted the impact of religion and culture on development. In this work, he says "Development" can only be measured consequent to the impacts that religion and culture have made on a given society [2]. These two variables are necessary in assessing the rate of development of a group of people or a nation for a period of time. The impact can either be positive or negative. Furthermore, he opined that the factors that influence sustainable development can be viewed from the following indices:

- Attitude to work and productivity;

- Values and norms guiding economic behavior;

- Motivation of people as economic agents;

- Consumption, saving and investment habits;

- Management and leadership styles;

- Entrepreneurship;

- Governance integrity, accountability and transparency. [2] [3] 
In my own critical assessment of this submission, one can agree with him if the issue is mainly based on economic parameters for development. As mentioned earlier, development can also be measured through social, political or religious parameter. The concern of this paper is to examine what role can Divine Injunction of Jesus in John 15:4 play in sustainable development. In this connection, if people heed to what Jesus says in verse 4 "Abide in me and I in you" can propel leaders and the led to have inclination of doing what is right than doing what is wrong. Doing wrong things consequently will hinder sustainable development.

Another factor that can enhance Sustainable Development is peace. Celestin Musekura says: "No Peace, No Development." [4]

Peace, no doubt is a strong factor for Sustainable Development. Peace is the heart and soul of development in any area of human endeavour. Any dream of democracy or social or economic development can only be realized in a stable and peaceful environment.

In Musekura's words, he says: "No nation on earth can prosper when her citizens are at war with each other and running to different directors for safety." [4] [5]

This statement is indisputable in the sense that when people live in fear and anxiety, there will be no constructive thought to plan for future development. The situation will be confusion here and there. Hence, to ensure a sustainable development in any aspect of any given people, peace is inevitable.

In 2000, the UN and some Western countries established what they called Millennium Development Goals known as MDGs, to enable Africa to reduce poverty by half, provide free universal primary education, clean water and so on.

Unfortunately, conflicts and unstable political atmosphere of many African countries have frustrated these efforts.

The 2008 G8 summit, addressing the problem of civil wars in Africa declared that peace and security of life and property are fundamental to stability in order to meet the needs of their people.

Fragile and post-conflict state remains farthest from reaching the MDGs.

In summary, sustainable development will always be a mirage unless the factors mentioned in this paper are in place and people are ready to heed to Divine Injunctions as enshrined in John 15:4.

The Exegetical Analysis of the Vine and the Branches in John 15:1-4 English Text of John 15:1-4:

${ }^{1}$ I am the true vine, and My Father is the vine-dresser.

${ }^{2}$ Every branch in Me that does not bear fruit, He takes away; and every branch that bears fruit He prunes, that it may bear more fruit.

${ }^{3}$ You are already clean because of the word which I have spoken to you.

${ }^{4} \mathrm{Abide}$ in $\mathrm{Me}$, and I in you. As the branch cannot bear fruit of itself, unless

it abides in the vine, neither can you, unless you abide in Me. (NKJV) 


\section{Greek Text of John 15:1-4}

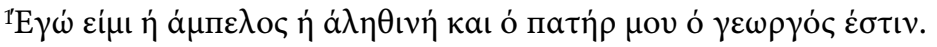

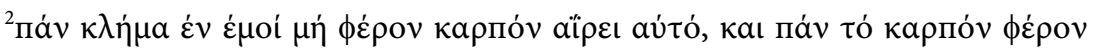

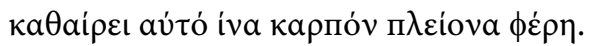

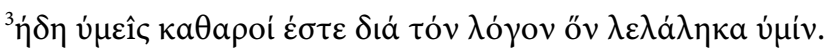

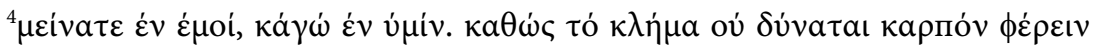

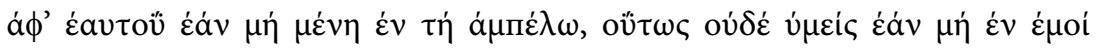
$\mu \varepsilon \dot{v \eta \tau \varepsilon . ~}$

\section{Historical Background}

Historically, Vineyards are kept in Israel not only for food but also for economic purposes. The major source of Israel economy comes from the proceeds of vineyard harvest every year. This implies that the "vine" is so significant in the source of livelihood of the people of Israel. Hence Jesus used the word "vine" to describe his work and ministry on earth as it relates to the salvation of humans. Throughout Israelites' history the vineyard played an important role in the agricultural and literary aspects of her religious development [6]. A fruitful vineyard was a symbol of God's faithful beneficence.

A large grape cluster from the vineyards of Eshcol Valley was brought back to the Israelite camp at Kadesh as evidence of great productivity of the Promised Land (Num 13:23-24, Deut 6:11). The vineyards would continue to be fruitful if the people observed the Lord's commandments (Deut 8:6-10).

The vine which is á $\mu \pi \varepsilon \lambda$ oc in Greek language is grape cultivated within the stone walls in vineyards [1] [7]. The word "vine" is often used as symbol for Israel in the Old Testament. In the Psalmist's appeal to God for help, he reminds the Lord "you brought a vine out of Egypt; you drove out the nations and planted it," (Ps. 80:8).

Prophet Isaiah also graphically applied this metaphor to Israel. According to him, Israel was a planted and tended vine by God in expectation of a sweet harvest of righteousness. But only the bitter grapes of injustice were found in God's field. God would tear down the protecting walls and let the enemies trample his vine (Is. 5:1-7). Other prophets also applied this imagery to Israel both in judgment (Jer. 2:21; Hosea 10:1) and in promise (Zec. 3:10).

In the New Testament, the vineyard which in Greek language is $\dot{\alpha} \mu \pi \varepsilon \lambda o v$ feature prominently.

In the New Testament, Jesus used similar imagery of the vine and the vine dressing in the text we are considering in this paper to describe the nature of discipleship by which the branches of his disciples bear abundant fruit as they are sustained and nurtured by the central vine in keeping his commandments (John 15:1-4).

\section{The Text}

Most significantly is Jesus "Identification of himself as the "True Vine"' in John 15:1. It is only by being a branch that draws continuously from the true 
vine that an individual can bring forth God's fruit of righteousness. Hence sustainability of spiritual growth and development rests on "Being in Christ and Christ being in us" (John 15:4). If Jesus is the true vine, then the father is the gardener in the vineyard and the disciples are the branches.

In Adeyemo's view "the fruit" here refers to both the holiness in the disciples own lives and their continuing service of Jesus [8]. Those branches that were not cut off could be pruned to make them produce more fruits. The "pruning" here refers to some of the pains the disciples experienced, for instance, Peter passed through punning of denying Jesus and there was restoration afterwards (Acts 18:17, 25, 21:19), mockery (Acts 2:12) and imprisonment (Acts 5:18). Each pruning experience gave him more energy to move on. We have to note here that the emphasis of this text is not on a believer losing salvation or being eternally secured but on those who have believed bearing fruit. One of the disciples that have already been "cut off" who was Judas Iscariot was replaced with Matthias could not be equated with a believer.

By bearing fruit, the disciples will both glorify God the father and also prove their discipleship. As branches the disciples have other specific responsibilities beside bearing fruit. They are also to love one another constantly expressed in the central theme of Johannine Theology. The meaning of the word "Pruning" in this text can be discovered from these three Greek words aipeı meaning "lift up"

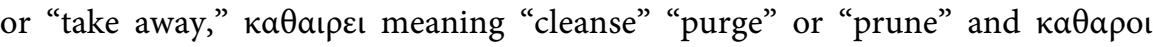
meaning "cleansed," "purged" or "pruned." The combination of these words

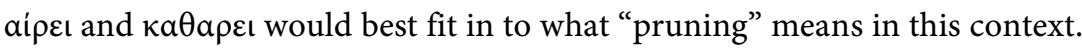

Vine dressers are known to lift up branches from the ground to enhance fruit bearing and to clean a dirty vine hence the combination of this words describe the process of bearing fruits in the mind of Jesus Christ i.e. aipel to describe

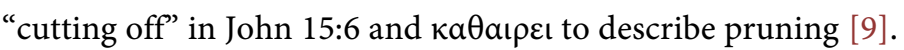

Purging, like pruning is a spiritual cleansing i.e. taking away the filth. This purging does serve as pruning and pruning will cause fruit-bearing. Fruit bearing here is the practical expression of the indwelling of the divine life of Christ. By implication, it means our lives should attract people to Christ and thus make them new members of God's vine.

Jesus assured fruit fullness to each branch abiding in the vine. However, abiding in the vine could be subjective and mystical that each believer could determine for himself what it entails.

The Implications of Johannine Thought on Sustainable Development in Nigeria

The Gospel of John is more topical than chorological. It revolves round the seven "I am" sayings of Jesus Christ out of which the text in reference in this paper is one. "I am the true vine" (John 15:1).

This gospel is always referred to in modern New Testament scholarships as the Theological and Spiritual interpretation of the historical account of Jesus life and ministry as recoded by the Synoptic Gospels (Mathew, Mark and Luke) for 
the fact that the gospel appeals to the sensitivity of believers about salvation of souls for which purpose Jesus came to fulfill, expressed in John 20:31.

But these are written that you may believe that Jesus is the Christ, the Son of God and the believing you may have life in His name.

As earlier mentioned, this text confirms Jesus mission and ministry. John wrote the gospel primarily to encourage those who already believed to continue in their faith. This is inferred from the use of present tense for the subjunctive

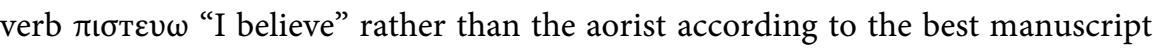
evidence. The aorist would have indicated initial believe, but the present indicates continual belief [9] [10]. If indeed John intended this Gospel to go to those who already believed, we can understand why this Gospel has so much more theological, spiritual and experiential depth than the synoptic gospels.

Without distracting from the other Gospels, it is generally admitted that John's gospel, is the most profound. At the same time, it is the most simple. New believers especially in the $21^{\text {st }}$ Century do benefit from its theological teachings the gospel presents including the text under consideration in this paper and so do the most mature people. The fact that Jesus' disciple had been chosen specifically is an encouragement for them to pass on this to the succeeding generations. Love is to be "the way of life" of true believers. They are to live in love with everybody and at all times. They would be hated and treated as enemies by the world. Three reasons are given for the hostility of the word:

a. The disciples do not belong to the world (John 15:19)

b. The world hated and persecuted Jesus their master (John 15:18)

c. The world lack knowledge of the father and of Jesus (John 15:21).

The disciples had previously belonged to the world but Jesus called them out of the world. Here the act of "choosing" gave the disciples a new status. The world's hatred of Jesus and rejection of his teachings had been openly expressed in persecution [8] [11]. The contemporary experience of religious conflicts especially is terror attacks against churches in the wake of Boko Haram attacks in Nigeria; the message of love becomes so significant.

John the Apostle who is supposed to be the author of John's gospel was conscious of the mind of Jesus Christ for calling his disciples out of whom he was one. The authority of preaching the gospel in making people appreciate the mission and ministry of Jesus on earth was not only given to Peter but to all the Apostles (John 20:33 cf. Matt. 18:15-20) [12].

When God empowers one to do his work he gives all he needs to accomplish it. The presence of Christ in an individual is the presence of power (John 15:4). The church in the $21^{\text {st }}$ Century is assured of God's presence as she fulfils the mission as it has been down the ages.

"Abiding in me and I in you" in John 15:4 is an assurance of divine presence of Jesus with His church at any given place and at any given time. The "I" $\varepsilon \gamma \omega$ cí $\mu$ is emphatic. Christ's continual abiding presence is one of the greatest and most precious promises and the sweetest realities (John 14:26, Act 1:45) [12] [13]. 
This assures believers of strength in their faith to face the turbulent experiences people face in the journey of life. Several efforts have been made and still being made by Christian. Organizations to organize Religious dialogue between Christians and Muslims in Nigeria over the years, but sadly this effort have not yielded positive results.

The message of John in John 15:1-4 is always a factor that calls for peaceful co-existence with non-Christians who exhibit hostility against the gospel of Christ especially in Muslim dominated areas in the Northern Nigeria "Living in the Spirit of Christ" according to Alister McGrath is compounded by the discussion at the academic level about "Prayer in the Spirit," "walking in the Spirit," "Life in the Spirit," baptism in the Spirit and even "Being Slain in the Spirit." [14] These phrases are often used carelessly and without definition. The issue here is not to address each of these phrases but to acknowledge the ambiguity of interest in spiritual renewal among the Christians of the $21^{\text {st }}$ Century.

With the message of John in the text, John 15:1-4 which Christian Theologians have used and are still using, not much has been achieved on sustainable development in Nigeria especially among Christian leaders. There still exist emptiness evidenced among church members and even church leaders. This has resulted in lives characterized by discouragement, frustration, problem of immorality which one can trace to faulty view of what conversation means. Others can be linked to the individualistic concept of Christianity.

Perhaps underlining all these problems is the obvious lack of Spiritual Theology in our expository study of biblical texts. In the view of Bassey Evanstis Spiritual Theology has been considered the domain of Roman Catholic Theology [15].

In the Contemporary experience, Christian Spirituality involves the choice we make "to know and grow" in our daily relationship with the Lord Jesus Christ by submitting to the ministry of the Holy Spirit. This means as believers, we make choice to keep our lives in Jesus Christ and allow him to live in us or refused to do this. Whatever choice we make suggests the consequence upon our lives and work. It should be noted that Christian Spirituality is the consciousness of fellowship with the Spirit of Christ, uninterrupted by carnality and sin. The question is: "is this what we experience today despite the biblical imperatives given by Jesus Christ in the New Testament?" The summary of the implications of Johannine thought can be identified as follows:

1) Perfect Union with Christ: A perfect union with Christ is the only means where by salvation is assured [16]. The privilege of justification is made possible when we walk in the spirit now and not in the flesh. For those who are Christ's, both the claiming and domineering power is broken. Christian leaders who ought to lead with life of integrity that can enhance sustainable development will do so if they live a life of perfect union with Christ.

2) The Righteousness of the Law is Fulfilled: Both in our justification and in our sanctification, the righteousness of the law is perfected. By implication, 
obedience of the law is fulfilled when the spirit of love is written on our hearts and that love is the fulfillment of the law. If this consciousness is imbibed by the stakeholders in every sector, the rule of law will be obeyed and sanity will be prevalent in our society.

3) The Gift of Life: If Christ is in us there is life John 3:6 cf. II Cor. 5:17. The body is dead to sin. "Life" here goes beyond the physical, even if the body is terminated by death, the soul lives eternally. The righteousness of Christ imputed and secures the soul eternally. The renewed image of God upon the soul preserve it and by God's ordination then there will be the fear of God in everything we do [16] [17].

4) God's Children by Adoption: The gift of adoption is another privilege. When one "lives in Christ and Christ in him" he becomes God's son by adoption. The word adoption here implies that all privileges and entitlements for the Son of God will also be for those adopted children. They are led by the spirit of God, loved and owned by him. Stability will manifest in governance. The crisis that pervade the entire life of the nation will reduce to the bearest minimum.

In Rom. 8:15 Paul re-affirms that in Christ, the bondage of fear is broken and the spirit of adoption is attained. Christ, the mediator has through his self-sacrifice obtained for us the adoption status. The Spirit of adoption works in the children of God a (friendly) love to God as the father having delight in him and dependence upon him for sustainability.

5) Heir of God's Kingdom: Those who live in Christ are heirs of God and joint heirs with Christ. Chris as the mediator is said to be the heir of all things (Heb. 1:2). True believers, by virtue of their union with him shall inherit all things (Rev. 21:7). Those that now partake of the Spirit of Christ, as his brethren shall as his brethren partake of his glory (John 17:24) and shall sit down with him upon his throne (Rev. 3:21). If we are convinced that this life is temporary and that a Day of Judgment will come; people will refrain from committing crimes with impurity.

6) The Spirit helps in Prayer: The Spirit helps us in prayer. The Spirit guides and teaches us how to pray. The Spirit inspires us what to say in prayer. The Spirit himself makes intercession for us i.e. the Spirit dictates our requests, inspires our petitions, draws up our plea for us. While Christ intercedes for us in heaven, the spirit intercedes for us in our hearts. The Holy Spirit is the spring of all our desires and breathings towards God.

\section{Conclusions}

No doubt that if Christians in the contemporary world heed to divine injunctions of Jesus Christ, Sustainable Development will be attainable in all spheres of human endeavours.

What we experience today is contrary to what Jesus expects from his followers, for instance, in politics, those who are Christians and Muslims who have moral values entrenched in their books (Bible and Quran) do not put this into 
consideration as they fulfill their roles as representatives of the people in Government. Evidences of moral decadence, doing wrong things with impurity, fill the pages of print media and even in the electronics media quite often of those who are expected to show good examples to the people as their political leaders. If this is the experience, we have among Christians and Muslims leaders in Nigeria, what do we expect from those who are non-religionists? This issue should be the concern of leaders in the two major religions we have in this nation, (Christianity and Islam) to intensify their efforts in entrenching religious culture and moral values into the lives of their members from where people go into politics. It is sure that if this is given adequate attention, much will be achieved in this regard.

\section{Conflicts of Interest}

The author declares no conflicts of interest regarding the publication of this paper.

\section{References}

[1] O. Lawrence Richard, (1985) Expository Dictionary of the Bible Words. Zondervan Corporation, Michigan, 576.

[2] Adei, S. (2009) Religion, Culture and Development. ILF Publishers, Orlando, 249.

[3] Adei, S. (2009) Religion, Culture and Development. ILF Publishers, Orlando, 254.

[4] Musekura, C. (2010) Peace: A Pre-Requisite for Development. ILF Publishers, Orlando, 196.

[5] Musekura, C. (2010) Peace: A Pre-Requisite for Development. ILF Publishers, Orlando, 197.

[6] Freedman, D. (2000) Eerdmans Dictionary of the Bible. William Eerdmans Publishing Company, Cambridge, 1356. https://doi.org/10.5117/9789053565032

[7] Lawrence Richard, O. (1985) Expository Dictionary of the Bible Words, 612.

[8] Adeyemo, T., Ed. (2006) African Bible Commentary. Zondervan Publishers, Nairobi, 1311 .

[9] Morris (2016) The Meaning of "Cleansing". Accessed from the Internet on 2nd February. https://www4.morris.umn.edu/

[10] Morris (2016) The Meaning of "Cleansing". Accessed from the Internet on 2nd February. https://www4.morris.umn.edu/

[11] Adeyemo, T., Ed. (2006) African Bible Commentary. 1312.

[12] Igbari, O. (2009) "I Am with You Always" (Matt. 28: 10), being a Paper presented at Abuja, 3.

[13] Igbari, O. (2009) "I Am with You Always" (Matt. 28: 10), 4.

[14] Alister, M. (1985) Luther's Theology of the Cross: Martin Luther's Theological Breakthrough. Basil Blackwell, Oxford, 147.

[15] Evanstis, B. (1993) Pentecostalism and the Catholic Church in Nigeria. Mariana Publishers, Calabar, 62.

[16] Igbari, O. (2009) More than Conquerors. A paper presented at Abuja, 1.

[17] Igbari, O. (2009) More than Conquerors. A paper presented at Abuja, 2. 